\section{Growing Interest in Teaching among U.S. College Faculty}

\section{Linda J. Sax}

Linda Sax is at the Higher Education Research Institute, University of California, Los Angeles.

$I^{n}$ n September, the Higher Education Research Institute at the University of California at Los Angeles released results of the 1995-1996 faculty survey, a national study of college faculty conducted on a triennial basis. The survey involved questionnaires completed by 59,933 faculty at 446 two-year colleges, four-year colleges, and universities in the United States. Of these, 33,986 questionnaires from 384 institutions judged to have surveyed the most representative samples of faculty were used to compute the national norms, which are statistically adjusted to represent the nation's total population of approximately 400,000 fulltime faculty. Following is a summary of the 1995-1996 results, including some comparisons with the 1989-1990 faculty survey, the first in this series of faculty surveys.

\section{Growing Interest in Teaching}

The most prominent theme that emerges from the 19951996 results is that U.S. faculty have become more focused on teaching. Currently, 75 percent of college faculty say their interests lean more toward teaching than research. When asked to describe "very important or essential" professional goals, fully 99 percent of faculty marked "being a good teacher," compared with 55 percent who marked "engaging in research.” This interest in teaching over research has grown since 1989 .

\section{The most prominent theme that emerges from the 1995-1996 results is that U.S. faculty have become more focused on teaching.}

However, while faculty in 1995 reported fewer hours spent on research than they did in 1989, the publication of journal articles and book chapters is up. This trend may very well reflect an increased "efficiency" among faculty due to a growing utilization of personal computers and advances in information technology.

\section{Changing Teaching Styles}

The survey also shows that U.S. faculty are adopting more "student-centered" instructional techniques. As compared with faculty in 1989 , faculty today are more likely to use collaborative instructional methods, such as cooperative learning and group projects. They are also more likely to adopt "progressive" teaching methods, such as computer-aided instruction and readings on racial/ethnic or women's/gender issues. Lecturing, perhaps the most traditional form of instruction, is on the decline. Gender differences show that while women are most likely to use the more progressive instructional methods, men are nevertheless beginning to adopt teaching styles that have traditionally been used by women faculty.

\section{The survey also shows that U.S. faculty are adopting more "student-centered" instructional techniques.}

\section{Faculty Embrace Diversity}

Perhaps the most striking shift between 1989 and 1995 has been an increased commitment to diversity and multiculturalism among U.S. faculty. Since 1989, faculty have become more likely to include issues of race, ethnicity, and gender in their research, writing, and teaching. Faculty today are also much more likely to have attended racial or cultural awareness workshops, and slightly more likely to have taught ethnic studies or women's studies courses.

\section{Women More Stressed Than Men}

In 1995, 33 percent of faculty reported experiencing "extreme" stress during the previous two years. Gender differences on this item are quite large, with 44 percent of women faculty reporting "extreme" stress, compared with 27 percent of men. Comparisons with 1989 show that although time pressures and lack of personal time continue to the greatest sources of stress for faculty, experiences with students have become increasingly more stressful (noted by 61 percent of faculty in 1995, compared with 50 percent in 1989). This increased stress may be due to the greater interaction with students that results from the use of the more progressive and student-oriented teaching methods adopted by faculty. Other sources of increased stress since 1989 reflect the more personal side of faculty members' lives: physical health, household responsibilities, and child care. 
Gender differences show that women are significantly more stressed than men on nearly all measures, including time pressures, lack of personal time, household responsibilities, teaching loads, and subtle discrimination. However, subtle discrimination as a source of stress shows the greatest decline between 1989 and 1995, down 14 percent for women. While it is possible that efforts to improve the climate for women in academe have been effective, the fact still remains that 34 percent of women (compared with 18 percent of men) continue to experience stress from subtle discrimination.

Gender differences show that women
are significantly more stressed than men
on nearly all measures, including time
pressures, lack of personal time, house-
hold responsibilities, teaching loads,
and subtle discrimination.

\section{Gender Differences in Salary Remain}

Based on constant 1995-1996 dollars, U.S. faculty in 1995 earn somewhat less than they did in 1989. This trend is consistent with national declines in constant dollar salaries for workers in all occupations, as reported by the U.S. Bureau of the Census. Further, while gender differences in faculty salaries are smaller than gender differences in most other occupations, women faculty still earn approximately 80 percent of salaries earned by men. A gender gap in salaries remains even when salaries are adjusted to take women's typically lower academic rankings into account.

For additional information on the faculty survey or to order the 1995-1996 normative results, please write or call: Higher Education Research Institute, University of California, Los Angeles, Graduate School of Education and Information Studies, 3005 Moore Hall/Mailbox 951521, Los Angeles, CA 90095-1521. Tel: (310) 825-1925; fax: (310) 206-2228; Internet: HERI@gse.ucla.edu.

\section{Problems of Private Higher Education in Russia}

\section{Evgenii Kodin}

Evgenii Kodin is vice rector, Smolensk State Pedagogical Institute, 4, Przhevalskii St., Smolensk 214000, Russia. He has been a visiting scholar at the Center for International Higher Education, Boston College during 1996.

$\mathrm{O}$ ne of the most visible changes in the Russian system of higher education today, as well as in many other transitional or politically reforming countries, is the emergence of private educational institutions. There are more than 200 private universities in Russia now, with annual enrollments of over 60,000 students. What benefits have they offered to society, and what problems do they face?

\section{Benefits}

To begin with, private universities have satisfied a need in areas of study unavailable in public institutions-courses and degrees in management, business, market economy, and other related subjects that simply did not exist in the Russian curriculum until recently.

Second, the private sector has provided a crucial avenue of access to higher education for thousands of students whom public educational institutions could not accept because of the limits imposed by state-planned enrollment.

Third, private higher education has provided parents with a legal opportunity to invest money in their children's future.

Finally, these institutions-through their less traditional missions and pedagogical approaches - offer young and energetic people a chance to develop academic and organizational skills, as well as providing opportunities for self-realization and self-expression.

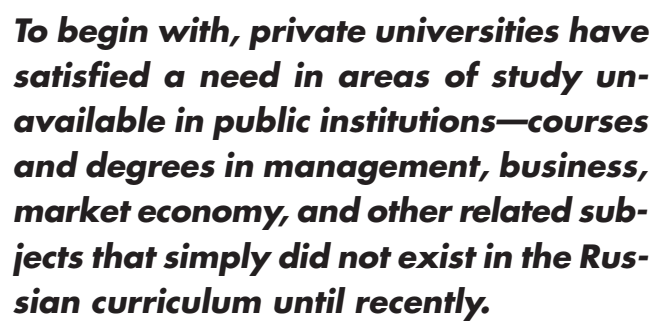

Some administrators of private universities admit now that they would never have entered the business of higher education if they had known the struggle they would face. 